\title{
Bioefficacy of different species of entomopathogenic fungi against white grub, Leucopholis lepidophora (Blanchard) infesting sugarcane in Maharashtra
}

\author{
PRADNYA B. MANE AND PANDURANG B. MOHITE
}

Division of Entomology, Mahatma Phule Krishi Vidyapeeth, College of Agriculture, KOLHAPUR (M.S.) INDIA

Email : pradnyamane03@gmail.com

\begin{abstract}
The bioefficacy of three species of entomopathogenic fungi viz., Metarhizium anisopliae (Metsch.) Sorokin, Beauveria brongniartii (Sacc.) and Beauveria bassiana (Balsana) Vuillrmin, against white grub, Leucopholis lepidophora (Blanchard) infesting sugarcane crop was studied under laboratory conditions. In this bioassay Metarhizium anisopliae fungus caused higher rate of grub mortality at an overall concentration range of $4 \times 10^{5}$ to $2 \times 10^{6}$ conidia $\mathrm{ml}^{-1}$ as compared to Beauveria brongniartii and Beauveria bassiana The treatments with Metarhizium anisopliae fungus was found to be most effective and recorded 34.48-58.62 per cent grub mortality on 15 DAT at different conidial concentrations. The fungi Beauveria brongniartii recorded 31.03-55.18 per cent grub mortality, while as in case of fungi Beauveria bassiana 24.14-51.72 per cent grub mortality was observed on 15 DAT at different conidial concentrations. The estimated LC ${ }_{50}$ values for $M$. anisopliae, B. brongniartii and B. bassiana towards third instar grubs of Leucopholis lepidophora Blanch. were $9.05 \times 10^{5}, 10.44 \times 10^{5}$ and $11.78 \times 10^{5}$ conidia $\mathrm{ml}^{-1}$, respectively.
\end{abstract}

Key words : Metarhizium anisopliae, Beauveria brongniartii, Beauveria bassiana, Leucopholis lepidophora, Sugarcane.

How to cite this paper : Mane, Pradnya B. and Mohite, Pandurang B. (2014). Bioefficacy of different species of entomopathogenic fungi against white grub, Leucopholis lepidophora (Blanchard) infesting sugarcane in Maharashtra. Asian J. Bio. Sci., 9 (2) : 234-237. 